\title{
NUTRITION BEHAVIOURS AND THE OCCURRENCE OF DEPRESSIVE SYMPTOMS AMONG THE STUDENTS IN THE INSTITUTIONS OF HIGHER EDUCATION IN SILESIA (POLAND)
}

\author{
Agnieszka Oleszko ${ }^{1}$ Elżbieta Szczepańska², Karolina Janion, Jadwiga Jośko-Ochojska
}

${ }^{1}$ Department of Environmental Medicine and Epidemiology, School of Medicine with the Division of Dentistry in Zabrze, Medical University of Silesia in Katowice, Poland ${ }^{2}$ Department of Human Nutrition, School of Public Health in Bytom, Medical University of Silesia in Katowice, Poland

${ }^{3}$ Department of Nutrition-Related Disease Prevention, School of Public Health in Bytom, Medical University of Silesia in Katowice, Poland

\begin{abstract}
Background. Depressive symptoms may appear at any age, yet they are most likely to be observed among young people aged 20-30. According to numerous scientific records, a properly balanced diet may prevent depression or enhance a therapeutical process.

Objective. The aim of the study was the assessment of nutrition behaviours and prevalence of depressive symptoms among the students, as well as investigation whereas there is a connection between these variables and the sexes of the examined group. Furthermore, the aim was to determine, whether there is a relation between proper nutrition behaviours and an intensification of depressive symptoms.

Material and methods. The research was conducted on a group of 959 students. In order to collect that data on nutrition behaviours an original anonymous questionnaire was used. In order to collect the data on a depressive symptoms occurrence Beck Depression Inventory (BDI-II) was used.

Results. Recommended number of meals was taken by $54.95 \%$ of students, including $59.20 \%$ of women and $48.56 \%$ of men. Only $6.25 \%$ of students, including $6.94 \%$ of women and $5.22 \%$ of men, ate a recommended number of 5 or more portions of fruit and vegetables. $11.16 \%$ of students, including $10.94 \%$ of women and $11.49 \%$ of men, drank at least 2 glasses of milk or dairy fermented products. $22.84 \%$ of students presented depressive symptoms. $11.57 \%$ of the examined people suffered from mild depression, $7.1 \%$ - of moderate depression and $4.17 \%$ - of a severe one.

Conclusions. It was found that there are relations between nutrition behaviours and sexes of the examined people. Women tend to present more beneficial behaviours. Almost every fourth student presented depressive symptoms - an intensification of the symptoms was more frequent among women. A growth in the rate of proper nutrition behaviours was connected with a drop in the depressive symptoms.
\end{abstract}

Key words: nutrition, students, depression

\section{STRESZCZENIE}

Wprowadzenie. Objawy depresyjne mogą pojawić się w każdym wieku, ale najczęściej młodych osób w wieku 20-30 lat. $\mathrm{Z}$ wielu doniesień naukowych wynika, że odpowiednio zbilansowana dieta może wykazywać działanie prewencyjne lub wspomagające proces terapeutyczny.

Cel badań. Ocena zachowań żywieniowych i częstości występowania objawów depresyjnych wśród studentów oraz sprawdzenie czy istnieją zależności pomiędzy tymi zmiennymi a płcią badanych osób. Ponadto celem było stwierdzenie, czy istnieje zależność pomiędzy prawidłowymi zachowaniami żywieniowymi a nasileniem objawów depresyjnych.

Material i metody. Badania przeprowadzono wśród 959 studentów. W celu zebrania danych dotyczących zachowań żywieniowych wykorzystano autorski anonimowy kwestionariusz ankiety, w celu zebrania danych dotyczących wystąpienia objawów depresyjnych wykorzystano skalę depresji Becka (BDI-II).

Wyniki. Zalecaną liczbę posiłków w ciągu dnia spożywało 54,95\% studentów, w tym 59,20\% kobiet i 48,56\% mężczyzn. Jedynie 6,25\% studentów, w tym 6,94\% kobiet i 5,22\% mężczyzn spożywało codziennie zalecane 5 lub więcej porcji warzyw i owoców. 11,16\% studentów, w tym 10,94\% kobiet i 11,49\% mężczyzn wypijało co najmniej 2 szklanki mleka lub mlecznych produktów fermentowanych. Wykluczenie słodyczy zadeklarowało 2,09\% studentów, w tym 1,39\% kobiet i 3,13\% mężczyzn,

Corresponding author: Elżbieta Szczepańska, Department of Human Nutrition, School of Public Health in Bytom, Medical University of Silesia in Katowice, Jordana Str. 19, 41-808 Zabrze, Poland, tel. +48 3227551 97, e-mail: eszczepanska@sum.edu.pl 
natomiast napojów słodzonych 11,37\% studentów, w tym 15,63\% kobiet i 4,96\% mężczyzn. Objawy depresji stwierdzono u 22,84\% studentów, depresja łagodna dotyczyła 11,57\%, umiarkowana - 7,1\%, ciężka - 4,17\% badanych osób.

Wnioski. Stwierdzono, że istnieją zależności między zachowaniami żywieniowymi a płcią badanych. Kobiety mają tendencję do prezentowania korzystniejszych zachowań. Niemal co czwarty student prezentował objawy depresyjne - nasilenie objawów było częstsze u kobiet. Wzrost odsetka prawidłowych zachowań żywieniowych związany był ze spadkiem objawów depresyjnych.

Słowa kluczowe: żywienie, studenci, kobiety, mężczyźni, depresja

\section{INTRODUCTION}

In the previous decades, along with the growth of availability and diversity of nutrition, the level of knowledge about its influence on health changed. More and more importance is attached to the promotion of a healthy lifestyle, i.e. a combination of a wellbalanced diet, a systematic physical activity, attention to a psychophysical balance and a lack of addictions [9]. Proper nutrition is one of basic factors which influence health as well as physical and psychological well-being. Proper nutrition is meant by regular meals and their optimal composition which covers organism's demand for energy and all the necessary nutrients. Therefore, daily nutrition habits are crucial, including food preferences, dietary patterns and the frequency of an intake of various food products [15].

According to numerous scientists, apart from social and environmental factors, it is a modern diet - poor in nutrients and mainly in vitamins and minerals, and rich in sugar, saturated fatty acids and trans type unsaturated fatty acids, that may have an impact on a higher rate of depression cases $[2,8,20,22,25]$. It was observed that such a diet often results in obesity which may lead to a higher risk of an occurrence of depression or its symptoms, especially among women $[1,2,5]$. Other authors claim that despite numerous gaps in the literature of this subject, there is strong evidence that a combination of healthy dietary patterns (including a higher intake of fruit, vegetables, legumes, whole-grain cereals, nuts and seeds, as well as a high consumption of food rich in polyunsaturated omega-3 fatty acids and a lower intake of processed food, fast food and sweets) may result in a lower risk of an occurrence of depression [13, 17, 23].

The aim of the research was to assess nutrition behaviours and estimate the frequency of an occurrence of depressive symptoms among the students in the institutions of higher education in Silesia, as well as the determination if there is a connection between these variables and the sexes of the examined groups. Furthermore, the aim was to determine whether there is a connection between proper nutrition behaviours and an intensification of depressive symptoms.

\section{MATERIAL AND METHODS}

The research was conducted on a group of 959 people including $576(60.06 \%)$ women and 383
(39.94\%) men, all of whom were students in the institutions of higher education in Silesia. 860 people (89.68\%), including $487(84.55 \%)$ women and 373 $(97.39 \%)$ men, were the undergraduate students and 99 people $(10.32 \%)$, including $89(15.45 \%)$ women and $10(2.61 \%)$ men were master-degree students or postgraduate student. 296 people including 213 (36.98\%) women and $83(21.67 \%)$ men studied Medicine or Medicine-related studies, and $663(69.13 \%)$ people, including 363 (63.02\%) women and 300 (78.33\%) men attended studies not related to Medicine. 60 people $(6.25 \%)$ were underweight, including $57(9.90 \%)$ women and $3(0.78 \%)$ men, 702 people $(73.20 \%)$ maintained a healthy weight, including $460(79.86 \%)$ women and $242(63.19 \%)$ men. $154(16.06 \%)$ students, including $49(8.50 \%)$ women and $105(27.42 \%)$ men were overweight. $41(4.28 \%)$ people, including 10 $(1.74 \%)$ women and $31(8.09 \%)$ men were obese. $2(0.21 \%)$ students did not reveal their body mass. Average BMI was $21.50 \mathrm{~kg} / \mathrm{m}^{2}\left(\mathrm{SD} \pm 3.00 \mathrm{~kg} / \mathrm{m}^{2}\right)$ for women, and $24.49 \mathrm{~kg} / \mathrm{m}^{2}\left(\mathrm{SD} \pm 3.99 \mathrm{~kg} / \mathrm{m}^{2}\right)$ for men.

The research was being conducted personally from May to June 2017. It was preceded by obtaining permission from the institution's authorities and the examined students. At the beginning of the research, participants were familiarized with an aim and a method of the research.

In order to collect that data on nutrition behaviours, an original anonymous questionnaire created and validated at the Department of Dietetics at Medical University of Silesia in Katowice, Poland was used. The questionnaire was composed of questions about nutrition habits, frequency of an intake of selected groups of food products, taken medicines, dietary supplements and physical activity, all of which with regard to 30 days preceding the examination. On the basis of a declared body mass $(\mathrm{kg})$ and height $(\mathrm{cm})$, Body Mass Index (BMI) was calculated for every examined student. It was interpreted in accordance with the criteria by the World Health Organization (WHO) [24]:

- $<18.5 \mathrm{~kg} / \mathrm{m}^{2}-$ underweight,

- $18.5-24.99 \mathrm{~kg} / \mathrm{m}^{2}$ - healthy body mass,

- $25.0-29.99 \mathrm{~kg} / \mathrm{m}^{2}$ - overweight,

$\cdot \geq 30.0 \mathrm{~kg} / \mathrm{m}^{2}-$ obesity.

In order to collect the data on a depressive symptoms occurrence (also in the last 30 days before 
the examination), Beck Depression Inventory (BDIII) was used. The following criteria were taken into consideration:

- 0-13 points - no depressive symptoms,

- 14-19 points - an intensification of depressive symptoms at a mild level (mild depression),

- 20-28 points - an intensification of depressive symptoms at a moderate level (moderate depression),

- 29-63 points - an intensification of depressive symptoms at a severe level (severe depression) [19].

Results were processed in Microsoft Office Excel 2010. Responses were analysed in total for the entire respondent and by sexes. A statistical analysis was conducted with Statistica 12.0 (StatSoft, Inc.). In order to determine nutrition behaviours of the examined people, proper behaviours was granted 1 point (in the analysis of results, presented with grey). It was possible to be granted with a maximal number of 17 points. Next it was investigated whether quantitative variables comply with the assumptions of a regular arrangement with a W Shapiro-Wilk test and charts of regularity. In order to determine the connection between a sex and a frequency of an intake of the selected food groups and an intensification of depressive symptoms (i.e. a result on a BDI-II scale), $\chi 2$ test of compatibility was used. Differences between proper nutrition behaviours by women and men were assessed with U MannWhitney's test. A connection between proper nutrition behaviours and an intensification of depressive symptoms (i.e. the number of points obtained on a BDI-II scale) was measured with a nonparametric Tau Kendall's test. Value of $\mathrm{p}<0.05$ was accepted as statistically important for all the analyses.

\section{RESULTS}

\section{Nutrition behaviours}

Students' selected nutrition behaviours are presented in Tables 1-4.

A recommended number of meals was eaten by $54.95 \%$ of students, including $59.20 \%$ of women and $48.56 \%$ of men. Meals were eaten every 3-4 hours by $43.59 \%$ of students, including $48.09 \%$ of women and $36.81 \%$ of men. Drinking a recommended amount of water was declared by $33.16 \%$ of students, including of $23.61 \%$ women and $47.52 \%$ of men. Thirst was most often quenched with water $(68.40 \%)$ - such a variant was chosen by $65.63 \%$ of women and $72.58 \%$ of men. Most of the students (51.40\%), including $57.81 \%$ of women and $41.78 \%$ of men did not add sugar to hot drinks (Table 1).

Table 1. Basic nutritional behaviours

\begin{tabular}{|c|c|c|c|c|c|c|c|}
\hline \multirow{2}{*}{ Nutrition behaviours } & \multirow{2}{*}{ Variants of the answer } & \multicolumn{2}{|c|}{ Women } & \multicolumn{2}{|c|}{ Men } & \multicolumn{2}{|c|}{ Total } \\
\hline & & $\mathrm{N}=576$ & $60.06 \%$ & $\mathrm{~N}=383$ & $39.94 \%$ & $\mathrm{~N}=959$ & $100 \%$ \\
\hline \multirow{4}{*}{$\begin{array}{l}\text { Number of meals } \\
\text { intake during the day }\end{array}$} & $1-2$ meals & 28 & 4.86 & 46 & 12.01 & 74 & 7.72 \\
\hline & 3 meals & 175 & 30.38 & 133 & 34.73 & 308 & 32.12 \\
\hline & 4-5 meals & 341 & 59.20 & 186 & 48.56 & 527 & 54.95 \\
\hline & $>5$ meals & 32 & 5.56 & 18 & 4.70 & 50 & 5.21 \\
\hline \multirow{4}{*}{$\begin{array}{l}\text { Breaks between } \\
\text { meals }\end{array}$} & $3-4 \mathrm{~h}$ & 277 & 48.09 & 141 & 36.81 & 418 & 43.59 \\
\hline & $4-6 h$ & 142 & 24.65 & 116 & 30.29 & 258 & 26.90 \\
\hline & $>6 \mathrm{~h}$ & 9 & 1.56 & 26 & 6.79 & 35 & 3.65 \\
\hline & Irregularly & 148 & 25.70 & 100 & 26.11 & 248 & 25.86 \\
\hline \multirow{4}{*}{$\begin{array}{l}\text { The amount of water } \\
\text { during the day }\end{array}$} & $<0.51$ & 32 & 5.56 & 4 & 1.04 & 36 & 3.75 \\
\hline & $0.5-1.01$ & 186 & 32.29 & 52 & 13.58 & 238 & 24.82 \\
\hline & $1.0-1.51$ & 222 & 38.54 & 145 & 37.86 & 367 & 38.27 \\
\hline & $>1.51$ & 136 & 23.61 & 182 & 47.52 & 318 & 33.16 \\
\hline \multirow{4}{*}{$\begin{array}{l}\text { The most intake drink } \\
\text { to satisfy your thirst }\end{array}$} & Water & 378 & 65.63 & 278 & 72.58 & 656 & 68.40 \\
\hline & Tea / coffee & 130 & 22.57 & 45 & 11.75 & 175 & 18.25 \\
\hline & Carbonated drinks & 39 & 6.77 & 42 & 10.97 & 81 & 8.45 \\
\hline & Juice & 29 & 5.03 & 18 & 4.70 & 47 & 4.90 \\
\hline \multirow{4}{*}{$\begin{array}{l}\text { Sweetening of hot } \\
\text { drinks with sugar* }\end{array}$} & 1 teaspoon & 146 & 25.35 & 97 & 25.33 & 243 & 25.34 \\
\hline & 2 teaspoons & 85 & 14.76 & 111 & 28.98 & 196 & 20.44 \\
\hline & $>2$ teaspoons & 12 & 2.08 & 15 & 3.91 & 27 & 2.82 \\
\hline & No sugar & 333 & 57.81 & 160 & 41.78 & 493 & 51.40 \\
\hline
\end{tabular}

*adding sugar to a $250 \mathrm{ml}$ glass

A relation between a sex of the examined people and a number of meals eaten a day was found $(p<0.01)$. According to the results for this group, women ate a recommenced number of meals a day much more often than men (Table 1).
According to an analysis of frequency of an intake of plant origin products, $93.33 \%$ of students had bread, however, a type of bread most often chosen was white bread - such a response was given by $48.91 \%$ of students, including $41.85 \%$ of women and $59.53 \%$ 
of men. Only $6.25 \%$ of students, including $6.94 \%$ of women and $5.22 \%$ of men had recommended 5 or more portions of fruit and vegetables a day. Maintaining a ratio of $3 / 4$ vegetables and $1 / 4$ fruit in an everyday diet was declared by $23.77 \%$ of students, including $22.05 \%$ of women and $26.37 \%$ of men. Oils were eaten on a daily basis by $6.78 \%$ of students, including $6.77 \%$ of women and $6.79 \%$ of men (Table 2).

A relation between sexes of the examined people and a consumed type of bread was found $(\mathrm{p}<0.01)$. According to the result, women chose brown bread much more often than men (Table 2).

Table 2. Intake of plant origin food products

\begin{tabular}{|c|c|c|c|c|c|c|c|}
\hline \multirow{2}{*}{ Nutrition behaviours } & \multirow{2}{*}{ Variants of the answer } & \multicolumn{2}{|c|}{ Women } & \multicolumn{2}{|c|}{ Men } & \multicolumn{2}{|c|}{ Total } \\
\hline & & $\mathrm{N}=576$ & $60.06 \%$ & $\mathrm{~N}=383$ & $39.94 \%$ & $\mathrm{~N}=959$ & $100 \%$ \\
\hline \multirow{4}{*}{$\begin{array}{l}\text { The most intake type } \\
\text { of bread }\end{array}$} & White bread & 241 & 41.85 & 228 & 59.53 & 469 & 48.91 \\
\hline & Brown bread & 269 & 46.70 & 111 & 28.98 & 380 & 39.62 \\
\hline & Other & 26 & 4.51 & 20 & 5.22 & 46 & 4.80 \\
\hline & Never & 40 & 6.94 & 24 & 6.27 & 64 & 6.67 \\
\hline \multirow{4}{*}{$\begin{array}{l}\text { Daily consumption } \\
\text { of vegetables and fruits }\end{array}$} & 1-2 portions & 342 & 59.38 & 280 & 73.11 & 622 & 64.86 \\
\hline & 3-4 portions & 185 & 32.12 & 67 & 17.49 & 252 & 26.28 \\
\hline & 5 or more portions & 40 & 6.94 & 20 & 5.22 & 60 & 6.25 \\
\hline & Never** & 9 & 1.56 & 16 & 4.18 & 25 & 2.61 \\
\hline \multirow{5}{*}{$\begin{array}{l}\text { Proportion of } \\
\text { vegetables and fruits in } \\
\text { the daily diet }\end{array}$} & $1 / 2$ vegetables $\& 1 / 2$ fruit & 256 & 44.45 & 151 & 39.43 & 407 & 42.44 \\
\hline & $3 / 4$ vegetables $\& 1 / 4$ fruit & 127 & 22.05 & 101 & 26.37 & 228 & 23.77 \\
\hline & $1 / 4$ vegetables $\& 3 / 4$ fruit & 170 & 29.51 & 111 & 28.98 & 281 & 29.30 \\
\hline & Only vegetables & 11 & 1.91 & 11 & 2.87 & 22 & 2.29 \\
\hline & Only fruit & 12 & 2.08 & 9 & 2.35 & 21 & 2.20 \\
\hline \multirow{4}{*}{$\begin{array}{l}\text { Frequency of intake of } \\
\text { plant oils }\end{array}$} & Every day & 39 & 6.77 & 26 & 6.79 & 65 & 6.78 \\
\hline & Several times a week & 185 & 32.12 & 123 & 32.11 & 308 & 32.12 \\
\hline & Several times a month & 268 & 46.53 & 170 & 44.39 & 438 & 45.67 \\
\hline & Never & 84 & 14.58 & 64 & 16.71 & 148 & 15.43 \\
\hline
\end{tabular}

**the answer relates to the daily intake of vegetables and fruit

According to an analysis of frequency of an intake of animal origin products, $11.16 \%$ of students, including $10.94 \%$ of women and $11.49 \%$ of men drank at least 2 glasses of milk or dairy fermented products such as natural yoghurt or kefir. Eating fish a several times per week was declared by $11.16 \%$ of students, including $10.59 \%$ of women and $12.01 \%$ of men. Having meat and cold meat a several times per week was confirmed by $42.55 \%$ of students, including $48.26 \%$ of women and $33.94 \%$ of men (Table 3 ).

Table 3. Intake of animal origin food products

\begin{tabular}{|c|c|c|c|c|c|c|c|}
\hline \multirow{2}{*}{ Nutrition behaviours } & \multirow{2}{*}{ Variants of the answer } & \multicolumn{2}{|c|}{ Women } & \multicolumn{2}{|c|}{ Men } & \multicolumn{2}{|c|}{ Total } \\
\hline & & $\mathrm{N}=576$ & $60.06 \%$ & $\mathrm{~N}=383$ & $39.94 \%$ & $\mathrm{~N}=959$ & $100 \%$ \\
\hline \multirow{4}{*}{$\begin{array}{l}\text { Frequency of intake of } \\
\text { milk or dairy fermented } \\
\text { products }\end{array}$} & $\geq 2$ glasses a day & 63 & 10.94 & 44 & 11.49 & 107 & 11.16 \\
\hline & $<2$ glasses a day & 224 & 38.89 & 152 & 39.69 & 376 & 39.21 \\
\hline & Occasionally & 265 & 46.00 & 176 & 45.95 & 441 & 45.98 \\
\hline & Never & 24 & 4.17 & 11 & 2.87 & 35 & 3.65 \\
\hline \multirow{4}{*}{$\begin{array}{l}\text { Frequency of intake of } \\
\text { fish }\end{array}$} & Every day & 0 & 0.00 & 2 & 0.52 & 2 & 0.21 \\
\hline & Several times a week & 61 & 10.59 & 46 & 12.01 & 107 & 11.16 \\
\hline & Several times a month & 458 & 79.51 & 303 & 79.11 & 761 & 79.35 \\
\hline & Never & 57 & 9.90 & 32 & 8.36 & 89 & 9.28 \\
\hline \multirow{4}{*}{$\begin{array}{l}\text { Frequency of intake of } \\
\text { meat and cold meat }\end{array}$} & Every day & 176 & 30.56 & 239 & 62.40 & 415 & 43.27 \\
\hline & Several times a week & 278 & 48.26 & 130 & 33.94 & 408 & 42.55 \\
\hline & Several times a month & 91 & 15.80 & 10 & 2.61 & 101 & 10.53 \\
\hline & Never & 31 & 5.38 & 4 & 1.05 & 35 & 3.65 \\
\hline
\end{tabular}

According to the analysis of an intake of products not recommended, exclusion of sweets was declared by $2.09 \%$ of students, including $1.39 \%$ of women and $3.13 \%$ of men and of sweet drinks - by $11.37 \%$ of students, including $15.63 \%$ of women and $4.96 \%$ of men. Elimination of fast-food products from a diet was declared by $17.31 \%$ of students, including $22.74 \%$ of women and $9.14 \%$ of men and of instant products - by $48.49 \%$ of students, including $53.82 \%$ of women and $40.47 \%$ of men (Table 4 ). 
Table 4. Intake of non-recommended products

\begin{tabular}{|c|c|c|c|c|c|c|c|}
\hline \multirow{2}{*}{ Nutrition behaviours } & \multirow{2}{*}{ Variants of the answer } & \multicolumn{2}{|c|}{ Women } & \multicolumn{2}{|c|}{ Men } & \multicolumn{2}{|c|}{ Total } \\
\hline & & $\mathrm{N}=576$ & $60.06 \%$ & $\mathrm{~N}=383$ & $39.94 \%$ & $\mathrm{~N}=959$ & $100 \%$ \\
\hline \multirow{4}{*}{$\begin{array}{l}\text { Frequency of intake of } \\
\text { sweets }\end{array}$} & Every day & 141 & 24.48 & 58 & 15.14 & 199 & 20.75 \\
\hline & Several times a week & 243 & 42.19 & 143 & 37.34 & 386 & 40.25 \\
\hline & Several times a month & 184 & 31.94 & 170 & 44.39 & 354 & 36.91 \\
\hline & Never & 8 & 1.39 & 12 & 3.13 & 20 & 2.09 \\
\hline \multirow{4}{*}{$\begin{array}{l}\text { Frequency of intake of } \\
\text { sweet drinks }\end{array}$} & Every day & 39 & 6.77 & 48 & 12.53 & 87 & 9.07 \\
\hline & Several times a week & 148 & 25.69 & 133 & 34.73 & 281 & 29.30 \\
\hline & Several times a month & 299 & 51.91 & 183 & 47.78 & 482 & 50.26 \\
\hline & Never & 90 & 15.63 & 19 & 4.96 & 109 & 11.37 \\
\hline \multirow{4}{*}{$\begin{array}{l}\text { Frequency of intake of } \\
\text { fast-food products }\end{array}$} & Every day & 6 & 1.04 & 5 & 1.31 & 11 & 1.15 \\
\hline & Several times a week & 47 & 8.16 & 54 & 14.10 & 101 & 10.53 \\
\hline & Several times a month & 392 & 68.06 & 289 & 75.45 & 681 & 71.01 \\
\hline & Never & 131 & 22.74 & 35 & 9.14 & 166 & 17.31 \\
\hline \multirow{4}{*}{$\begin{array}{l}\text { Frequency of intake of } \\
\text { instant products }\end{array}$} & Every day & 4 & 0.69 & 9 & 2.35 & 13 & 1.35 \\
\hline & Several times a week & 28 & 4.86 & 28 & 7.31 & 56 & 5.84 \\
\hline & Several times a month & 234 & 40.63 & 191 & 49.87 & 425 & 44.32 \\
\hline & Never & 310 & 53.82 & 155 & 40.47 & 465 & 48.49 \\
\hline
\end{tabular}

A relation between sexes of the examined people and a frequency of an intake of sweet soft drinks was found ( $<<0.01$ ). According to the results, women chose such products much less often than men (Table 4).

Based on the Shapiro-Wilk test and charts of regularity the rate of proper nutrition behaviours variable was not found to be with the assumptions of a regular arrangement $(p<0.05)$. In the next analysis, differences between a rate of proper nutrition behaviours by women and men were observed $(p<0.01)$ (Table 5).

Table 5. Rate of proper nutrition behaviours

\begin{tabular}{|c|c|c|c|c|}
\hline \multicolumn{2}{|c|}{ Variable } & Median & Lower-upper quartile & Name and test result \\
\hline \multirow{2}{*}{ Sex } & Women & 29.41 & $23.53-41.18$ & \multirow{2}{*}{ U Mann-Whitney's test; $\mathrm{p}<0.01$} \\
\cline { 2 - 5 } & Men & 29.41 & $17.65-35.29$ & \\
\hline \multicolumn{2}{|c|}{ Total } & 29.41 & $17.65-41.18$ & \\
\hline
\end{tabular}

Taking medicines and dietary supplements and of men. Sedatives were taken by $9.07 \%$ of students, physical activity

Taking medicines and dietary supplements by students is presented in Table 6, and their physical activity - in Figure 1.

Taking medicines was declared by $20.23 \%$ of students, including $23.61 \%$ of women and $15.14 \%$ including $10.59 \%$ of women and $6.79 \%$ of men. Dietary supplements were used by $34.62 \%$ of students, including $35.94 \%$ of women and $32.64 \%$ of men. Supplementation of vitamin D was declared by $6.78 \%$ of people, including $9.38 \%$ of women and $2.88 \%$ of men (Table 6).

Table 6. Taking medicines and using dietary supplements

\begin{tabular}{|c|c|c|c|c|c|c|c|}
\hline \multirow{2}{*}{ Nutrition behaviours } & \multirow{2}{*}{ Variants of the answer } & \multicolumn{2}{|c|}{ Women } & \multicolumn{2}{|c|}{ Men } & \multicolumn{2}{c|}{ Total } \\
\cline { 2 - 8 } & & $\mathrm{N}=576$ & $60.06 \%$ & $\mathrm{~N}=383$ & $39.94 \%$ & $\mathrm{~N}=959$ & $100 \%$ \\
\hline \multirow{2}{*}{ Taking medicines } & Yes & 136 & 23.61 & 58 & 15.14 & 194 & 20.23 \\
\cline { 2 - 8 } & No & 440 & 76.39 & 325 & 84.86 & 765 & 79.77 \\
\hline \multirow{3}{*}{ Taking sedatives } & Yes, regularly & 11 & 1.91 & 6 & 1.57 & 17 & 1.77 \\
\cline { 2 - 8 } & Yes, occasionally & 50 & 8.68 & 20 & 5.22 & 70 & 7.30 \\
\hline \multirow{2}{*}{$\begin{array}{c}\text { Using dietary } \\
\text { supplements }\end{array}$} & No & 515 & 89.41 & 357 & 93.21 & 872 & 90.93 \\
\hline \multirow{2}{*}{$\begin{array}{c}\text { Vitamin D } \\
\text { supplementation }\end{array}$} & Yes & 207 & 35.94 & 125 & 32.64 & 332 & 34.62 \\
\cline { 2 - 9 } & No & 369 & 64.06 & 258 & 67.36 & 627 & 65.38 \\
\hline \multirow{2}{*}{ Yes } & 54 & 9.38 & 11 & 2.88 & 65 & 6.78 \\
\hline
\end{tabular}


The examined students undertook physical activity for at least 30-45 minutes, most often for a several times a week. Such a respond was given by $41.08 \%$ of people, including $40.08 \%$ of women and $41.52 \%$ of men. Physical activity was undertaken daily by $12.72 \%$ of students, including $8.16 \%$ of women and
$19.58 \%$ of men (Figure 1). A relation between sexes of the examined people and undertaking physical activity was found $(p<0.01)$. According to the results, women undertake physical activity much less often than men (Figure 1).

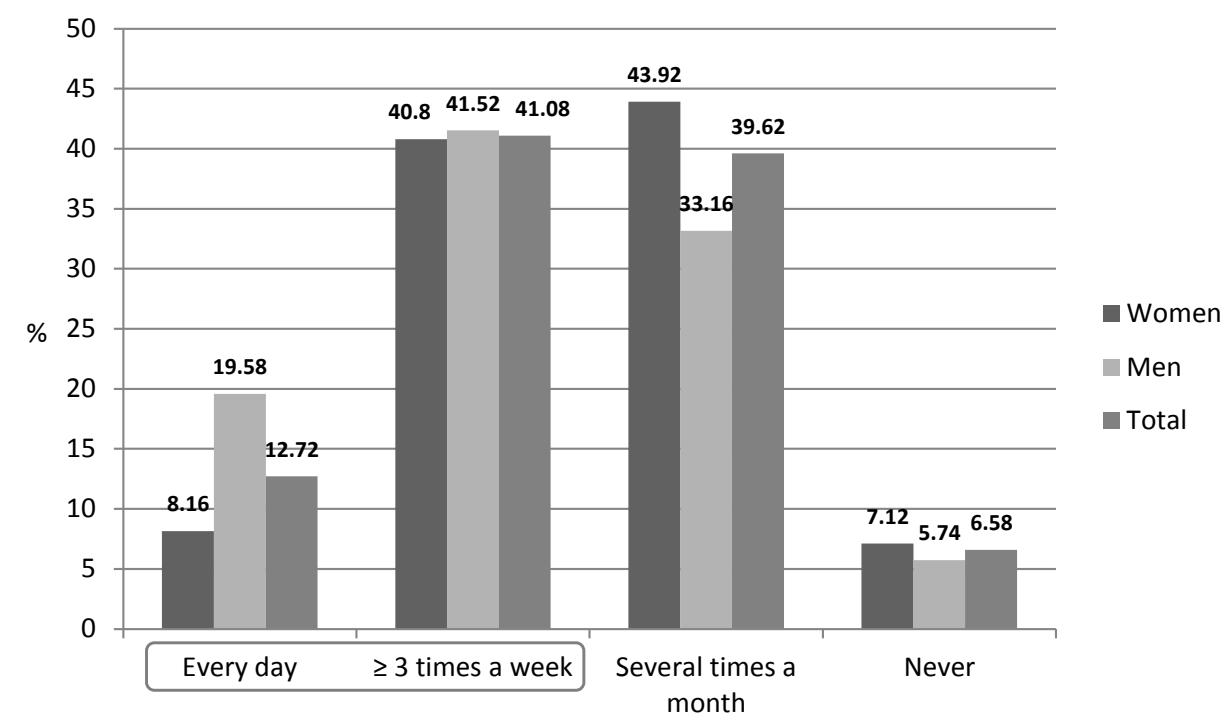

Figure 1. Physical activity taking 30-45 minutes

\section{Role of food}

The examined students claimed that apart from nutrition, eating is relaxing and gives them pleasure - such a respond was given by $47.76 \%$ of students, including $48.96 \%$ of women and $45.95 \%$ of men. For $21.48 \%$ of students food has mainly a pro-health role
- students declared to pay special attention to health and nutrition values of food. $17.41 \%$ of students like eating with other people and for them eating has got a social role. The lowest number of students $(13.95 \%)$ considered an emotional role of food (reduction of stress) (Figure 2).

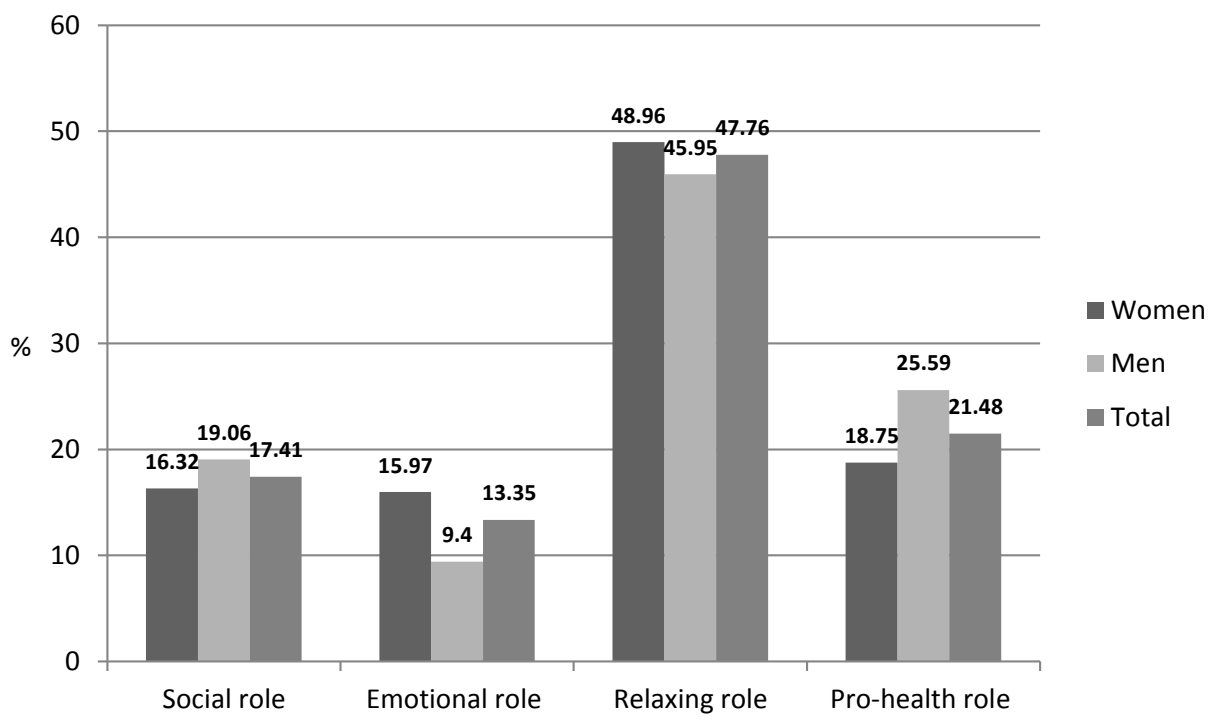

Figure 2. Role of food, beyond satisfying hunger

Intensification of depressive symptoms on a BDI-II scale

Mood of the examined people was assessed using a BDI-II scale. It oscillated between 0 and 53 points with a median of 7 points (bottom-top quartile: 3-13 points). For women, the results were between 0 and 50 points with a median of 5 (bottom-top quartile: 3-14 points) and for men, the results were between 0 and 53 points with a median of 5 (bottom-top quartile: 2-11 points).

Depressive symptoms were observed in $22.84 \%$ of students: symptoms which might suggest mild depression - in $11.57 \%$, moderate 
depression - in 7.1\%, and severe depression - in $4.17 \%$ of the respondents (Figure 3 ).

A relation between sexes of the examined people and an intensification of depressive symptoms was found (a result on a BDI-II scale), $(\mathrm{p}<0.01)$. According to the results, depressive symptoms were observed much more often in women than men (Figure 3).

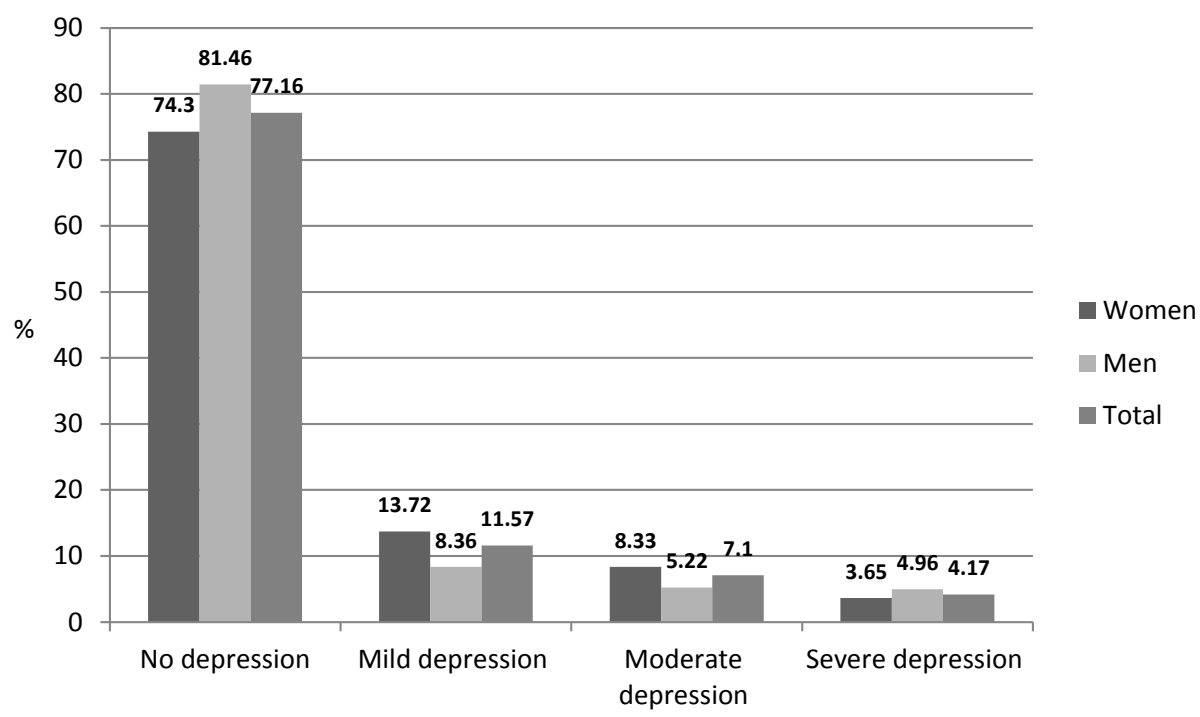

Figure 3. Severity of depression symptoms according to the BDI-II scale

It was also investigated, whether there is a relation between a percent of proper nutrition behaviours and an intensification of depressive symptoms (i.e. points on a BDI-II scale). According to the results in the examined group, an increase in proper nutrition behaviours generated a drop in depressive symptoms (Tau Kendall's $=-0.09 ; \mathrm{p}<0.01$ ).

\section{DISCUSSION}

In the recent years, more and more young people have been diagnosed with a mood decline. However, in Poland this data is only fragmentary and results of the conducted research are difficult to compare due to methodology [4]. According to WHO, by 2020 depression will have been on a $2^{\text {nd }}$ position in the global burden of diseases [6]. People at any age may be diagnosed with it, yet the first symptoms usually appear at the age of 20-30 and an incidence rate is higher in a group of women. This may be determined by neurobiological, hormonal and social and cultural differences between the sexes $[4,6]$. According to the results of the personal research, women are diagnosed with a mood decline more often. Also in the research by Jaworska et al., which aim was to assess mood and humour of 153 students at the University School of Physical Education in Wroclaw, Poland, more cases of an occurrence and/or an intensification of depressive symptoms were observed in a group of women, which is an evidence that this sex may be a risk factor [4].

People diagnosed with depressive symptoms tend to have eating disorders. Most often, these are problems with appetite and changes in food preferences. Eating too much or too less and irregularity in meals may result in improper body mass, nutrition deficiencies and worse mood [5, 21]. People whose BMI indicated overweight or obesity frequently had problems of psychological origin. Low self-esteem and lack of self-confidence are just a few emotional states that may result in a withdrawal from an active life [5].

In a research by Leszczyńska et al., in which an impact of emotions on nutrition behaviours of 90 women aged 18-30 years was estimated, it was observed that in a group of women who tended to suffer from a mood decline, overweight was more common than in a group of women who did not. Furthermore, women classified to a group with mood decline tendencies ate sweets more often, which may be connected with a stress-eating phenomenon [10]. According to a personal research, everyday sweets intake was higher in a group of women than in a group of men $(24.48 \%$ vs $15.14 \%)$. What is more, it was a group of men, which declared to undertake everyday physical activity more frequently. Such results may suggest that in case of men, physical activity is a preferred method for stress relieve and dealing with other difficult situations in everyday life.

A well balanced diet, both in terms of quantity and quality, is beneficial for the functioning of a nervous system. Long-term deficiencies of vitamins and minerals may account for the occurrence of psychological disorders [21]. According to the latest research on the relation between vitamin $\mathrm{D}_{3}$ and an occurrence and/or an intensification of depressive symptoms, deficiency of this vitamin enhances the risk of depression. Supplementation of vitamin $\mathrm{D}_{3}$ 
by people with depression disorders had an antidepressant effect and prevented its relapses [20]. In Poland, there are deficiencies of this vitamin in a population. According to personal research, only $6.78 \%$ of students supplements this vitamin. Such a respond was chosen more often by women than men $(9.38 \%$ vs $2.88 \%)$.

In the recent years, perception of food and its impact on health has undergone changes. A role of a dietician and various nutrition patterns in the treatment of various diseases, including depression, are more often emphasized [17]. Nevertheless, relations between a diet quality and nutrition behaviours and depression are not fully comprehensible yet. According to a systematic review of scientific papers conducted in 2013 in order to estimate these relations, diet modifies key biological factors connected with the development of depression, yet there are no sufficient evidences for it. Various types of diet were investigated: a Mediterranean diet, a Norwegian diet, a Japanese diet, a "western" diet and a healthy diet in a broad sense [14].

In a review of scientific papers published in 2016, connections between eating food by children and the adolescent, and depression and depressionrelated psychological problems, lack of a homogenous methodology and negligence of important environmental and social and economic factors, which influence the research parameters, were criticized. Yet despite some inconsistent results, this research is an evidence for the relation between healthy eating habits and a high-quality diet, and a lower level of depression occurrence. They also present a connection between a low-quality diet and an occurrence of depression or a bad psychological condition [7]. According to the research on 1000 men in Finland, it was proven that a balanced diet determined lower risk of a depressive symptoms occurrence, whereas a "western" diet model correlated with a more frequent occurrence depressive symptoms. Compliance with a healthy diet model was also connected with a lower risk of depression requiring hospitalization [18].

According to some research, some nutrition patterns - especially a Mediterranean and a Norwegian one - may result in a lower risk of depression among adults. This seems to be consistent in various countries, cultures and populations. Patterns potentially connected with a lower risk of depression are the ones based on seafood, fruit and vegetables and nuts. However, current evidence is still limited and research in this subject should be continued [11]. In the research by Nasir et al. all the possible relations between main nutrition patterns and depression, stress and anxiety among adults were shown. According to the authors, better compliance with a healthy diet led to a decrease in an average depression result $(\mathrm{p}=0.03)$ and an anxiety rate $(\mathrm{p}=0.03)[12]$.
Based on the current scientific information, it seems important to complete an assessment of nutrition behaviours among young people, especially among those who are prone to depressive symptoms. Apart from the authors, such assessment was completed inter alia by Ilow et al., who analysed nutrition habits of students from Wroclaw Medical University. According to the authors, improper nutrition habits were observed among a significant part of students, especially men [3]. When interpreting the results, it is important to take into account the fact that the respondents in both personal research and the research by Ilow et al. were Medicine students. Based on the review of the research, depression is observed relatively frequently in this group - it is estimated to be ca. $27.2 \%$. It might be caused by the specificity of these studies, which is connected with strong stress, anxiety and competition between students $[3,16]$.

Our research have shown that nutrition behaviours are varied in the examined group. Women tend to present more beneficial nutrition behaviours. However, in this group depressive symptoms are observed more frequently.

\section{CONCLUSIONS}

1. Students' nutrition behaviours varied. It was found that there are relations between nutrition behaviours and sexes of the examined people. Women tend to present more beneficial behaviours. Differences between a rate of proper behaviours by women and men were observed.

2. Almost every fourth student presented depressive symptoms. It was found that there is a relation between an intensification of depressive symptoms and sexes of the examined people - an intensification of the symptoms was more frequent among women.

3. There is a relation between proper nutrition habits and an intensification of depressive symptoms a growth in the rate of proper nutrition behaviours was connected with a drop in the depressive symptoms.

\section{Conflict of interest}

The authors declare no conflict of interest.

\section{REFERENCES}

1. Frisco M.L., Houle J.N., Lippert A.M.: Weight change and depression among US young women during the transition to adulthood. Am J Epidemiol 2013;178:2230 doi: 10.1093/aje/kws462.

2. Glibowski P., Misztal A.: Wpływ diety na samopoczucie psychiczne [Effect of diet on mental well-being]. Bromat. Chem. Toksykol. 2016;49(1):1-9 (in Polish). 
3. Ilow R., Regulska-Ilow B., Różańska D.: Dietary habits of Wroclaw Medical University students (Poland). Rocz Państw Zakl Hig 2017;68(1):23-32.

4. Jaworska L., Morawska N., Morga P., SzczepańskaGieracha J.: Analiza częstości występowania objawów depresyjnych wśród studentów Wydziału Fizjoterapii Akademii Wychowania Fizycznego we Wrocławiu w kontekście planów zawodowych [Analysis of the prevalence of depressive symptoms among students of the Faculty of Physiotherapy, University School of Physical Education in Wroclaw in the context of career plans]. Fizjoterapia 2014;22(3):10-22 (in Polish).

5. Jośko-Ochojska J., Lizończyk I.: Występowanie depresji u młodzieży z nadwagą i otyłością [Prevalence of depression in overweight and obese adolescents]. Hyg Pub Health 2014;49(4):690-695 (in Polish).

6. Jurkiewicz B., Kotpa M.: Stres a ryzyko wystąpienia depresji u ludzi młodych w przedziale wiekowym 2035 lat [Stress and the risk of developing depression among young people aged between 20 and 35]. Probl Pielęgn 2015;23(1):13-19 (in Polish).

7. Khalid S., Williams C.M., Reynolds S.A.: Is there association between diet and depression in children and adolescents? A systematic review. $\mathrm{Br}$ J Nutr. 2016;116(12):2097-2108 doi:10.1017/ S0007114516004359.

8. Kjargaard M., Joakimsen R., Jorde R.: Low serum 25-hydroxyvitamin $\mathrm{D}$ levels are associated with depression in an adult Norwegian population. Psychiat. Res. 2011;190(2-3):221-225 doi:10.1016/j. psychres.2011.06.024.

9. Kucharska E.: Poprawa zdrowia poprzez prawidłowe żywienie i aktywność fizyczną [Improving health by improving nutrition and physical activity]. W: Podgórska M. red. Choroby XX wieku - wyzwania W pracy fizjoterapeuty [Diseases of the twentieth century - challenges in the work of a physiotherapist]. Gdańsk, Wydawnictwo Wyższej Szkoły Zarządzania 2017 (in Polish).

10. Leszczyńska S., Błażejewska K., LewandowskaKlafczyńska K., Rycielski P.: Emocje a zachowania żywieniowe u kobiet w wieku 18-30 lat [Emotions and eating behaviors among females aged 18-30]. Endokrynol Otyłość 2011;7(3):167-171 (in Polish).

11. Martinez-Gonzales M.A., Sanchez-Villegas A.: Food patterns and the prevention of depression. Proc Nutr Soc. 2016;75(2):139-146 doi:10.1017/S0029665116000045.

12. Nasir Y., Rahimi M-H., Molahosseini M., Yekaninejad S., Maghbooli Z., Mirzaei K.: The association of major dietary patterns with depression, anxiety and stress in apparently healthy adults. JNSD 2018;2(5).

13. Opie R.S, Itsiopoulos C., Parletta N., Sanchez-Villegas A., Akbaraly T.N., Ruusunen A., Jacka FN.: Dietary recommendations for the prevention of depression. Nutr Neurosci. 2017;20(3):161-171; doi:10.1179/1476 830515Y.0000000043.

14. Quirk S.E., Williams L.J., O'Neil A., Pasco J.A., Jacka F.N., Housden S., Berk M., Brennan S.L.: The assotiation between diet quality, dietary patterns and depression in adults: a systematic review. BMC Psychiatry. 2013;13:175 doi:10.1186/1471-244X-13-175.
15. Rasińska R.: Nawyki żywieniowe studentów w zależności od płci[Dietary habits of students depending on the sex]. Nowiny Lekarskie 2012;81(4):354-359 (in Polish).

16. Rotenstein L.S., Ramos M.A., Torre M., Segal J.B., Peluso M.J., Guille C., Sen S., Mata D.A.: Prevalence of Depression, Depressive Symptoms, and Suicidal Ideation Among Medical Students: A Systematic Review and Meta-Analysis. JAMA 2016;316(21):22142236; doi:10.1001/jama.2016.17324.

17. Róg J., Karakuła-Juchnowicz H.: Rola dietetyka w opiece nad pacjentem z zaburzeniami psychicznymi [The role of dietitian in care of a patient with psychiatric disorder]. Psychoterapia i Uzależnienia 2017;2:1-8 (in Polish).

18. Ruusunen A., Lehto S.M., Mursu J.: Dietary patterns are associated with the prevalence of elevted depressive symptoms and the risk of getting a hospital discharge diagnosis of depression in middle-aged or older Finnish men. J Affect Disord. 2014;159:1-6 doi:10.1016/j. psychres.2017.04.020.

19. Smarr K.L., Keefer A.L.: Measures of depression and depressive symptoms: Beck Depression Inventory-II (BDI-II), Center for Epidemiologic Studies Depression Scale (CESDS), Geriatric Depression Scale (GDS), Hospital Anxiety and Depression Scale (HADS), and Patient Health Questionnaire-9 (PHQ-9). Arthrit Care Res. 2011;63(S11):454-466 doi:10.1002/acr.20556.

20. Stefanowski B., Antosik-Wójcińska A., Święcicki Ł.: Wpływ niedoboru witaminy $\mathrm{D}_{3}$ na poziom nasilenia objawów depresyjnych. Przegląd aktualnych badań [The effect of vitamin D3 deficiency on the severity of depressive symptoms. Overview of current research]. Psychiatr. Pol. 2017;51(3):437-454 (in Polish).

21. Stefańska E., Wendołowicz A., Kowzan U., Konarzewska B., Szulc A., Ostrowska L.: Czy zwyczajowy sposób żywienia pacjentów z depresją wymaga suplementacji witaminami i składnikami mineralnymi? [Does the usual dietary intake of patients with depression require vitamin-mineral supplementation?] Psychiatr. Pol. 2014;48(1):75-88.

22. Szczygiet D., Kadzikowska-Wrzosek R.: Emocje a zachowania żywieniowe - przegląd badań. Zeszyty Naukowe Akademii Morskiej w Gdyni [Emotions and eating behaviors - a research review] 2014; 86:69-77 (in Polish).

23. Wendołowicz A., Stefańska E., Ostrowska L.: Influence of selected dietary components on the functioning of the human nervous system. Rocz Panstw Zakl Hig 2018;69(1):15-21.

24. WHO. Obesity: preventing and managing the global epidemic. Report of a WHO Consultation. WHO Technical Report Series 894. Geneva: World Health Organization, 2000.

25. Wilczyńska A.: Kwasy tłuszczowe w leczeniu i zapobieganiu depresji [Fatty acids in treatment and prevention of depression]. Psychiatr Pol. 2013; 47(4):657-666 (in Polish).

Received: 05.11.2018

Accepted: 06.02.2019 